\title{
How Listed Companies Implement Sustainable Development Strategy in Environmental Protection
}

\author{
Han Ling \\ Hohai University \\ Nanjing, China \\ heidihl@foxmail.com
}

\author{
Meng Qingjun \\ Hohai University \\ Nanjing, China \\ mqj@hhu.edu.cn
}

\begin{abstract}
In order to explore how listed companies involving in the environmental protection can get sustainable development in the competition, this paper adopts case analysis method. Through selecting the Capital Group share Ltd. Co. in Shanghai stock exchange of China a share market, this paper figures out problems and puts forward countermeasures by analyzing the annual report and other information. Through the analysis of the problems, it's finally concluded that listed companies involving in the environmental protection still face huge challenges while their development ushered in a lot of opportunities, such as lack of funds and technical support. Therefore, it's necessary to strengthen independent innovation with support of the state. The product image of listed companies involving in environmental protection is not quite beautiful, so it's imperative to focus on the brand image promotion. The brand must be supported by core competitiveness. In addition, this enterprise calls for a huge and long investment, which needs the support of the financial industry. Finally, it's necessary to strengthen the cooperation between the media and research institutes in order to expand the market and obtain social recognition, thus cultivating an image and attracting talents.
\end{abstract}

Keywords-environmental protection; listed companies; sustainable development; core competitiveness

\section{INTRODUCTION}

In 2014, the deputy general manager of Capital Group Liu Yongzheng said the feature of scale and internationalization prevails in China's environmental protection enterprises in the future. By means of technological innovation mode etc., it's expected to create business model with Chinese characteristics of synchronized governance and development. In the course of operation, there are many factors that have a remarkable effect on the implementation of sustainable development strategy of listed environmental companies, such as stock market volatility, corporate funds, technology or corporate governance and other factors. Environmental protection listed companies are composed of private and state-owned companies [1]. Sustainable development strategy refers that it is necessary to consider the business objectives and improve the enterprise market position in the pursuit of self-survival and sustainable development process, but also to maintain a sustained profit growth and ability improvement in the leading areas of competition and the operation environment of future expansion, to ensure that the enterprises are enduring in a long period of time.
Internationally, the concept of environmental protection occurred in the public awareness among a series of ecological disasters in the 20th century. After the end of World War II, the foreign economy has gained an extremely rapid development [2]. Since 1970s, the United States successively formulated or revised a series of environmental protection bills, which covered more and more laws and increasingly strict standard. From perspective of the law formation, Clean Water Act and Clean Air Act have been formed. The Obama administration has ever spent $\$ 90$ billion on clean energy and green jobs, who has also developed the nation's first comprehensive national marine management policy. In 1985, China regarded the environmental protection as a basic national policy, and began to seriously deal with and solve the country's outstanding environmental problems, to promote economic, social and environment harmonious development and to implement the sustainable development strategy. The Environmental Protection Law of the People's Republic of China has been implemented for nearly 30 years, which has promoted the construction of ecological civilization in China. In recent years, many environmental protection policies emerge, including the 10-Chapter Soil Pollution Action Plan and the ten-measure action plan to tackle water pollution, etc.

To analyze from the financing aspect, in addition to financing in the securities market, listed environmental companies often enjoy some financial supports, and the existence of bank loans, foreign investment, government bonds and other auxiliary financing channels. These companies are increasingly paying attention to the use of diversified financing models, but there are restraints on technology, capital, environmental protection policies and other factors.

\section{RELATED RESEARCH}

Due to the fierce industrial competition and management as well as other reasons, a lot of environmentally friendly listed companies run into the interference in the implementation of sustainable development strategy, it is necessary to be analyzed Qiao Zengguang think, the sustainable development strategy in environmental protection companies refers to the pursuit of long-term sustainable development under the constraints of the various resources that it can obtain. To form its core competitiveness in the long term through market positioning, product development, technological innovation and other means, and then continue to self-transcend, improve and 
enhance its core competitiveness, and cultivate corporate culture. To overcome the constraints of products and enterprises life cycle through institutional innovation and technological innovation and other ways, to form the long-term competitive advantage of the enterprises and to improve the market competitiveness of the enterprises, in order to achieve sustainable development of the enterprises [3]. The development foot hold of the environmental protection enterprises should fall in the effective improvement of their own technology and operational level, so as to achieve the sustainable development.

Bruce R. Barringer, Foard F. Jones and Donald 0.Neubaum said in the study in 2005 that, high growth represented the market's recognition of the enterprise, and indicated the success of the enterprise's current operation. Through the study of many growing enterprises, they came up with four factors that had important influence on the sustainable growth of the enterprises: business practice, human resource management, enterprise attributes and founder characteristics. Through the study of the data of 8405 production enterprises in nearly 10 years in 2007, Alex Coad made empirical analysis of profitability indicators had played a small role in the sustainable growth. Ren Yinghan (2014) analyzed the financial profitability, growth ability and cash flow financial index of the SSE 50 index stocks from 2009 to 2013, and the results showed that the stock price was highly correlated with the financial indicators representing the profitability and growth ability of the enterprise, while the correlation with the cash flow indicators was low.

In 2015, China began the "The Belt and Road" construction. So far, China has cooperated with Pakistan, Laos, Tehran and other countries to complete many environmental protection projects, in which the most famous environmental protection enterprises include China Energy Conservation and Environmental Protection Group and Fujian Lonk Limited.Co.

\section{CASE AnAlysis: BeiJing CAPITAL Shares}

\section{A. The Reasons of Analysis of Beijing Capital Shares (600008)}

The company's time to the market is an early one of environmental protection companies [4]. Seen from the annual report of the company and other information, the report of the Third Plenary Session of the 18th Central Committee in 2013 clearly put forward the construction of ecological civilization system. This series of policies has brought tremendous impetus to the environmental protection industry. With the implementation of BOT and mergers and acquisitions ways, the water investment and the engineering project of Beijing Capital Co., Ltd. had excellent benefits, so the stock price in that year showed an upward trend. In the first half of 2015, the national level PPP project began to land, the company continued to develop water market through BOT, TOT, mergers and acquisitions, etc., and successfully involved in solid waste and other fields, at the same time, the company has undertaken national special issues over the years, and extensively cooperated with universities and research institutes, forming its own strong technical level, in addition, the stock market in 2015 was the bull market, so the company's stock was soaring.
2016 was the first year of the reform of the supply front, and also the first year of the "thirteenth five plan". The opening was a strong momentum, but the stock fell later due to being affected by the stock market environment. Therefore, the state support is the basis for the stable development of the enterprises. From the overall environment, the macro factors have the largest impact on the listed environmental companies. When the country introduces the relevant policies to encourage environmental protection, the listed environmental protection companies will rise in stock prices. In addition, tax preference will make the final profits retained in the company increase, and finally the part allocated to the shareholders will increase. Such as the current domestic popular PPP model, it is also originated in the United Kingdom first. The model had been issued in the 1990s. On the cooperation between the British government and the British Landon Envirotech Ltd, there have been contracts and regulatory problems in the process, but that have been effectively solved later [5].

\section{B. The Strategy Factors Affecting the Company to Implement Sustainable Development}

\section{1) External factors} avoided

a) Fierce industrial competition is difficult to be

At present, in order to further occupy and consolidate the market position of various enterprises in the domestic environmental protection industry, the listed environmental companies have to speed up regional development planning and layout. Beijing, Jiangsu, Yunnan, Hunan and other provinces and cities have become the key areas that the listed environmental protection companies seize. Some listed large environmental companies plan the market business through the establishment of branch offices, the industrial competition is becoming increasingly fierce, which will lead to part of the investment of the investors will be raised to the stock of other listed companies, the share prices of their own companies will have a certain decline. So, in order to avoid this situation, and to obtain a stable investment for the company, environmental protection listed companies should enhance their own strength and have a foot hold in the industry, so as to stabilize the company's stock price. For example, if the most direct impact factors of the stock price changes are the amount of buying and selling, then when a listed company is well-known, there will be a lot of investors paying attention to its stock and buying, to enhance the stock price.

\section{b) Shortage of financial support}

From perspective of the environmental protection enterprise's survival environment, China's environmental protection industry has just begun to rise, which lacks financial support in all aspects. However, it takes long time for environmental protection to bring benefits. Meanwhile, the initial $R \& D$ expenditure is huge, which makes the environmental protection companies' lack of financial support become a common phenomenon, thus greatly restricting the development of enterprises. When some environmental protection enterprises seek loans from banks or other financial institutions, banks often refuse to grant loans for various reasons such as non-compliance, which makes the financing 
ways of environmental protection companies limited. Other companies may seek to raise money on the market by getting listed, but the conditions are so severe that start-ups are unlikely to meet the requirements, so few companies can obtain capital by tapping into it.

\section{2) Internal problems}

\section{a) Lack of core competitiveness}

Now the environmental protection equipment is to install the technology into a closed space in a direct way, which is short of creativity, making consumers be unwilling to go out to use. If the listed environmental protection companies want to broaden the sales channels, the design must be beautiful. Although the environmental protection equipment on the market has the role of purification of the environment, the appearance still needs to be improved. For example, the antihaze mask has a filter on the mouth, which affects the appearance, but it can not play the role of anti-haze without this filter. In the environmental protection listed companies, talents are the mainstay, without them, the companies will not have product innovation. Many environmental listed companies are still unable to retain the talents after the use of the increasing in payment, the release of benefits and equity. Environmental protection is a project with huge initial investment, and the late recovery of funds is slow. During the period, it is easy to have bad management if there is no support of external funds. The company should establish a good credit relationship with financial institutions, banks, etc. in order to have financing facilities.

\section{b) Low cost control level}

Environmental protection enterprises can hardly control the cost when studying environmental protection products or conducting scientific research experiments. Since many experiments may fail, the final research results can be quite precious. However, this part of the cost can be halved to the final price, which is finally payed by consumers. Therefore, the ability to control costs affects the profitability of an enterprise. If the cost is moderate and the product price is reasonable, the consumer who is willing to buy the product will increase, otherwise the customer will run away.

\section{How To IMPLEMENT SUSTAINABLE DEVELOPMENT STRATEGY IN THE COMPANIES}

\section{A. Building the Brand, to Enhance the Core Competitiveness}

The brand building is a long-term process, and if it is generally known by the public, there are more opportunities to be retrieved in the stock market, and the situation that no one will buy will not occur. The brand awareness of consumers mostly begins in the terminal, so the enterprises must be paid more attention in the terminal in order to enhance brand awareness and show a good brand image. Terminal expressive force includes: terminal visibility, terminal display specifications, and the quality of the terminal staff, etc. That the terminal performance is good or bad will have a direct impact on the brand building. Like the anti-haze masks, the haze masks at the beginning have various kinds, but gradually, the user experience, service attitude will separate them into different levels. At the same time, these changes will indirectly affect the stock prices, so the brand building has a great impact on the share prices of the environmental protection listed companies.

\section{B. The Company's Products are Innovative, to Design Applicable Products}

Environmental protection listed companies should visit the research institutes and institutions of higher learning as well as other institutions based on the shortcomings of existing technology, to learn the relevant technology and to improve their products to better meet the needs of consumers, to design the applicable products. The products designed should highlight the characteristics of the products, and carry out quality testing to ensure that environmentally friendly products meet environmental requirements, and are really effective in the using process. That will not affect the personal image as taking out with you. This is also a way for listed companies to promote themselves, increasing profits and the stock prices through sales can explain people's recognition of environmentally friendly products.

\section{Improve the level of internal control}

A highly competitive company will inevitably form a huge organizational structure and the implementation of internal control must call for guarantee from the organization. In the operation process of listed companies, the independence of the organization can hardly be realized. Therefore, enterprises may seek to some frauds, thus failing to achieve the target. In addition, another reason is that the enterprise's internal control cannot keep up with the operation of enterprises. In order to realize the strategy of sustainable development, managers in these companies shall have a strong internal control ability, who shall establish internal control system, thus ensuring the consistency between internal control and enterprise development strategy [6].

\section{To Strive to Gain the Supports of the Financial Industry}

The development of green finance is to service for the green industry by using green credit, bonds and other financial tools, which can stimulate funds to enter the field of environmental protection. At present, the market of the new financing model is still in the initial stage. First of all, various regions should be advocated to relax the financing conditions for the environmental protection listed companies, to carry out the investment and financing activities by introducing the thirdparty funds, to obtain sufficient funding sources for the environmental listed companies. Second, the listed environmental companies can also obtain funds by way of listing. Then, the green bonds, accounts receivable financing, finance leasing, carbon finance, asset securitization and other emerging financial instruments should be increased. Finally, you can also carry out the financing for the environmental protection projects. When financial institutions put more investment in environmental protection listed companies, it indicates that they think the company is worth holding, and the stock will be raised [7]. 
E. Mutually Beneficial Cooperation with Chinese and foreign News Media, Research Institutes and Other Organizations

Cooperating with Chinese and foreign news media to promote corporate branding, raise awareness, and provide better credit for financing by reporting on pollution incidents, solutions and implementation results. Cooperation with institutions and colleges can attract technical talents and enhance the skills of employees, and also to complete the relevant environmental projects, to achieve mutual benefits and win-win situation. This can not only attract talents and technology, but also solve the employment problem of college students. Working with the accounting firm can know about the company's financial deficiencies and improve the management. Through the cooperation with the relevant well-known institutions, listed environmental protection companies can improve the goodwill to be more competitive in the industrial competition. In order to make better use of these resources, you can build a production and research cooperation exchange platform, and the technology and capital are regarded as the most important communication content [8]. Cooperating with foreign companies is also a choice.

\section{CONCLUSION}

Although the environmental protection companies usher in the development opportunities, its development will still be obstructed by a number of factors. For example, although the number of private enterprises is large, the bankruptcy problems are serious because of the lack of financial and technical support. Since 2008, the country has begun to attach great importance to the environmental protection industry, relaxing the conditions and providing greater support in the tax, financing and other aspects, such as the release of "Ten Measures for Preventing and Controlling Air Pollution", "Ten
Measures for Preventing and Controlling Water Pollution", these policies have a positive impact on the development of the environmental protection listed companies. Therefore, with the support of national policies, through the cooperation with financial and research institutes and other relevant organizations, these companies shall make efforts to enhance the core competitiveness in the long term, in order to implement the sustainable development strategy.

\section{REFERENCES}

[1] Zhao Bi, Beijing Municipal Government Investment and Financing Research under the Perspective of Sustainable Development [D], Chinese Academy of Fiscal Sciences, 2012 (1).

[2] Li Boyang, Guo Tingzheng, The Comparison and Enlightenment of the Development of Domestic and Listed Foreign Environmental Companies [J], China Science and Technology Investment, 2012 (1)

[3] Qiao Zengguang, Enterprise Sustainable Development and Its Evaluation Research[D], Hunan University, 2004 (1)

[4] GuXiaozhong, Lin Lin, Innovation Research of Environmental Protection Listed Companies underthe Perspective of Innovation Chain Taking Wuhan Kinghome Environmental Technologies Co., Ltd. as an example [J], Science \& Technology Progress and Countermeasures, 2016.33 (23): 92-97.

[5] UK Department of Environment, Food and Rural Affairs. Reform of the pumping management system: take full advantage of every drop of water $[\mathrm{EB} / \mathrm{OL}]$ https://www.gov.uk/government/consultations/reforming-the-waterabstraction-management-system-making-the-most-of-every-drop.

[6] Li Xiaofang. Analysis on Internal Control of Environmental Protection Enterprises[J]. Financial Circle (Academic Edition), 2017 (2): 137-139.

[7] Li Xiaoxi, Xia Guang, Cai Ning, Green Finance and Sustainable Development [J], Financial Forum, 2015 (10): 30-40.

[8] Gao Yang, The dilemma and countermeasure of law specialty of independent college under the background of "production and research" [J], Legal expo, 2017 (5): 51-5. 